\title{
Evaluation of the anticancer potential of six herbs against a hepatoma cell line
}

\author{
Natthida Weerapreeyakul ${ }^{1,2^{*}}$, Apiyada Nonpunya ${ }^{3}$, Sahapat Barusrux ${ }^{2,4,5}$, Thaweesak Thitimetharoch ${ }^{1,2}$ \\ and Bungorn Sripanidkulchai ${ }^{1,2}$
}

\begin{abstract}
Background: Six herbs in the Plant Genetics Conservation Project that have been used as complementary medicines were chosen on the basis of their medicinal value, namely Terminalia mucronata, Diospyros winitii, Bridelia insulana, Artabotrys harmandii, Terminallia triptera, and Croton oblongifolius. This study aims to evaluate the potential anticancer activity of $50 \%$ ethanol-water extracts of these six herbs.

Methods: Fifty percent ethanol-water crude extracts of the six herbs were prepared. The cytotoxicity of the herbal extracts relative to that of melphalan was evaluated using a hepatoma cell line (HepG2), and examined by neutral red assays and apoptosis induction by gel electrophoresis and flow cytometry after $24 \mathrm{~h}$.

Results: A significant difference was found between the cytotoxicity of the $50 \%$ ethanol-water crude extracts and melphalan $(P=0.000)$. The $50 \%$ ethanol-water crude extracts of all six herbs exhibited cytotoxicity against HepG2 cells, with $I C_{50}$ values ranging from 100 to $500 \mu \mathrm{g} / \mathrm{mL}$. The extract of $T$. triptera showed the highest cytotoxicity with an $I_{50}$ of $148.7 \pm 12.3 \mu \mathrm{g} / \mathrm{mL}$, while melphalan had an $\mathrm{I}_{50}$ of $39.79 \pm 7.62 \mu \mathrm{g} / \mathrm{mL}$. The $50 \%$ ethanol-water crude extracts of $D$. winitii and T. triptera, but not A. harmandii, produced a DNA ladder. The 50\% ethanol-water crude extracts of D. winitii, T. triptera, and A. harmandii induced apoptosis detected by flow cytometry.
\end{abstract}

Conclusion: The 50\% ethanol-water crude extracts of D. winitii, T. triptera, and A. harmandii showed anticancer activity in vitro.

\section{Background}

The Plant Genetics Conservation Project, under the patronage of Her Royal Highness Princess Maha Chakri Sirindhorn, aims to evaluate the biochemical activities and properties of potential medicinal plants. Previously, cytotoxic and apoptotic effects of medicinal plants found in Chaiyaphum province have been discovered [1] Therefore, subsequent studies were extended for herbs in other Plant Genetics Conservation Project areas, including Terminalia triptera Stapf and Terminalia mucronata Craib \& Hutch in Combretaceae, Croton oblongifolius Roxb. and Bridelia ovata Decne in Euphorbiaceae, Diospyros winitii Fletcher in Ebenaceae, and Artabotrys harmandii Finet \& Gagnep. in Annonaceae.

\footnotetext{
* Correspondence: natthida@kku.ac.th

${ }^{1}$ Faculty of Pharmaceutical Sciences, Khon Kaen University, Khon Kaen, 40002, Thailand

${ }^{2}$ Center for Research and Development of Herbal Health Products (CRDHHP), Faculty of Pharmaceutical Sciences, Khon Kaen University, 123 Mittrapap Road, Muang District, Khon Kaen, 40002, Thailand

Full list of author information is available at the end of the article
}

Except for T. mucronata and A. harmandii, the other four herbs are all found in China [2,3].

The abovementioned herbs are commonly used in Asia $[2,3]$. For example, the bark of T. triptera is used with betel nuts as a remedy for aphthous ulcer [3]. Meanwhile, for $C$. oblongifolius, its leaves are used as a tonic for indigestion, flatulence, and bruises, its flowers for the treatment of flat worms, its fruit for dysmenorrhea, its seeds as a purgative, its roots for dysentery, and its bark for dyspepsia, chronic hepatomegaly, and fever [3]. The medicinal use of $D$. winitii is unclear. The longstanding medicinal use of these herbs necessitates research into their clinical safety and rigorous biological activity testing. Since cancer is a leading cause of death worldwide [4], evaluation of the anticancer activity of these herbs is the first priority. It was previously reported that labdane diterpenoids extracted from the stem bark of C. oblongifolius exert moderate cytotoxicity toward cancer cell lines [5].

\section{Biomed Central}

(c) 2012 Weerapreeyakul et al.; licensee BioMed Central Ltd. This is an Open Access article distributed under the terms of the Creative Commons Attribution License (http://creativecommons.org/licenses/by/2.0), which permits unrestricted use, distribution, and reproduction in any medium, provided the original work is properly cited. 
In this study, determination of anticancer activity was based on the cytotoxicity of $50 \%$ ethanol-water crude extracts toward a human hepatocarcinoma cell line, HepG2. Cytotoxicity and selectivity were determined for the safety of the $50 \%$ ethanol-water crude extracts using a normal African green monkey kidney epithelial cell line, Vero, relative to the HepG2 cell line. Apoptotic cell death is a protective mechanism that destroys misprogrammed or nonfunctional cells and is used as a clinical endpoint for effective anticancer treatment [6,7]. The apoptosis-inducing effects were determined in HepG2 cells by examination of DNA fragmentation, which is observed as DNA laddering by agarose gel electrophoresis. The apoptosis-inducing effects of the plant extracts were further confirmed using Annexin V-FITC staining and detection by flow cytometry.

In this study, we aims to investigate the anticancer activity of six herbs based on their cytotoxicity and apoptosis induction.

\section{Methods}

\section{Chemicals and reagents}

Dulbecco's modified Eagle's medium (DMEM), fetal bovine serum (FBS), penicillin, and streptomycin were purchased from GIBCO $^{\circledR}$ (Invitrogen, USA). Dimethylsulfoxide (DMSO) and ethidium bromide were purchased from Sigma-Aldrich (USA). Sodium bicarbonate, neutral red (NR), and melphalan in powder form were purchased from Sigma-Aldrich (Germany). Isopropyl alcohol (biotechnology grade) was purchased from Bio Basic Inc. (USA). Methanol (analytical grade) was purchased from BDH (England). A FlexiGene DNA Kit was obtained from Qiagen (Germany). Agarose (molecular grade) was purchased from Bio-Rad (USA), and an
$100 \mathrm{bp}+1.5 \mathrm{~Kb}$ DNA ladder with stain was purchased from SibEnzyme (Russia). All other reagents used in this study were purchased from Sigma Chemicals Co. (USA). An Annexin V-FITC Apoptosis Detection Kit was purchased from Bender MedSystems GmbH (Austria).

\section{Herb materials}

Twigs of the six herbs were collected and authenticated by Assistant Professor Thaweesak Thitimetharoch based on the taxonomy [TT, OC \& SK-number]. The vouchers were deposited at the Herbal Herbarium, Faculty of Pharmaceutical Sciences, Khon Kaen University, Khon Kaen Province, Thailand. The details of the herbs and voucher numbers are summarized in Table 1.

\section{Herb extractions}

Fifty percent ethanol-water crude extracts were prepared from the dried stems of each herb, which were cut and macerated with $50 \%$ ethanol-water at a ratio of $1 \mathrm{~kg} / 6 \mathrm{~L}$ for 7 days with occasional shaking. The solvent was filtered, distilled in vacuo using a rotary evaporator (Rotavapor R-200; Büchi Labortechnik AG, Switzerland) below $40^{\circ} \mathrm{C}$, and freeze-dried to obtain the $50 \%$ ethanolwater crude extracts. The $50 \%$ ethanol-water extracts were freshly prepared as stock solutions in DMSO.

\section{Gas chromatography/mass spectrometry (GC-MS) analysis} A gas chromatography system (Model $6890 \mathrm{~N}$; Agilent Technologies, China) coupled with a mass selective detector (Model 5973 N; Agilent Technologies, USA) and a GC autosampler (HP 7683 series) were employed for all analyses. Samples were separated on a 30.0-m long, 250- $\mu \mathrm{m}$ diameter, $0.25-\mu \mathrm{m}$ film thickness, 122-5532 DB-5 ms capillary column from Agilent Technologies

Table 1 Cytotoxicity of the $50 \%$ ethanol-water crude extracts based on the neutral red assay, and the scientific name, family, part used and \% yield

\begin{tabular}{|c|c|c|c|c|}
\hline \multirow{2}{*}{$\begin{array}{l}\text { Scientific name (Voucher specimen no.) } \\
\text { T. triptera }\end{array}$} & \multirow{2}{*}{$\begin{array}{l}\text { Family } \\
\text { Combretaceae }\end{array}$} & \multirow{2}{*}{$\begin{array}{l}\text { \% yield per gram } \\
\text { dry weight }\end{array}$} & \multicolumn{2}{|c|}{ Cytotoxicity $\left(I C_{50}\right.$ value, $\left.\mu \mathrm{g} / \mathrm{mL}\right)$} \\
\hline & & & $136.4 \pm 44.5$ & $148.7 \pm 12.3$ \\
\hline \multicolumn{5}{|l|}{ [T, OC \& SK No 1214, 1224] } \\
\hline C. oblongifolius & Euphorbiaceae & 6.18 & $238.9 \pm 21.9$ & $378.4 \pm 18.7$ \\
\hline \multicolumn{5}{|l|}{ [T, OC \& SK No 1215, 1256] } \\
\hline D. winitii & Ebenaceae & 4.13 & $>500$ & $204.7 \pm 33.5$ \\
\hline \multicolumn{5}{|l|}{ [TT, OC \& SK No 1245] } \\
\hline B. ovata & Euphorbiaceae & 5.68 & $>500$ & $183.9 \pm 7.1$ \\
\hline \multicolumn{5}{|l|}{ [TT, OC \& SK No 1253] } \\
\hline A. harmandii & Annonaceae & 3.28 & $309.7 \pm 58.2$ & $163.5 \pm 11.7$ \\
\hline \multicolumn{5}{|l|}{ [TT, OC \& SK No 1264] } \\
\hline T. mucronata & Combretaceae & 3.93 & $129.4 \pm 18.4$ & $152.0 \pm 33.2$ \\
\hline \multicolumn{5}{|l|}{ [TT, OC \& SK No 1269] } \\
\hline Melphalan & & & $59.9 \pm 3.2$ & $37.7 \pm 9.8$ \\
\hline
\end{tabular}


(J\&W Scientific, USA). The column initially flowed at $80^{\circ} \mathrm{C}$ for $6 \mathrm{~min}$ with a rate of $2 \mathrm{~mL} / \mathrm{min}$ and an average velocity of $52 \mathrm{~cm} / \mathrm{s}$. The temperature was then raised to $280^{\circ} \mathrm{C}$ (at a rate of $5^{\circ} \mathrm{C} / \mathrm{min}$ ) and maintained for $24 \mathrm{~min}$. The total runtime was $70 \mathrm{~min}$. Ultrapure helium with an inline Alltech oxygen trap was used as the carrier gas (19.34 psi), with the purge flow set at $20.0 \mathrm{~mL} / \mathrm{min}$, the purge time set at $0.75 \mathrm{~min}$, and a total flow of $24.3 \mathrm{~mL} /$ min. The injector temperature was maintained at $250^{\circ} \mathrm{C}$, and the injection volume at $2.0 \mu \mathrm{L}$ in the splitless mode. The interface temperature was held at $280^{\circ} \mathrm{C}$. Mass spectra were scanned from $\mathrm{m} / z 50.0$ to $\mathrm{m} / \mathrm{z} 500.0$ at a rate of $1.5 \mathrm{scans} / \mathrm{s}$ with a threshold of 150 . The electron impact ionization energy was $70 \mathrm{eV}$. The chemical components of the crude extracts were identified from the chromatograms and mass spectra using the Wiley 7 N.l database (Agilent Technologies).

\section{Cell culture}

The HepG2 and Vero cell lines were maintained at the Center for Research and Development of the Medical Diagnostic Laboratories, Khon Kaen University. DMEM was supplemented with $10 \% \mathrm{FBS}, 100 \mathrm{U} / \mathrm{mL}$ penicillin, and $100 \mu \mathrm{g} / \mathrm{mL}$ streptomycin. The cells were cultured at $37^{\circ} \mathrm{C}$ under a humidified atmosphere containing $5 \% \mathrm{CO}_{2}$.

\section{Cytotoxicity based on NR assays}

The stock solutions of the herb extracts in DMSO were diluted with DMEM to the desired concentrations (10$500 \mu \mathrm{g} / \mathrm{mL}$ ). The maximum concentration of the $50 \%$ ethanol-water extracts in each test was $500 \mu \mathrm{g} / \mathrm{mL}$, such that the final concentration of DMSO would not exceed $1 \%(\mathrm{v} / \mathrm{v})$ and the cytotoxicity of DMSO would be less than $10 \%$. The HepG2 hepatoma cell line and normal Vero cell line were used as the cell models. The cytotoxicity evaluation was performed using NR assays according to Fotakis and Timbrell [8], with some modifications. Melphalan was used as a standard anticancer drug for comparisons with the crude extracts.

The cells were seeded in 96-well plates at a density of $3 \times 10^{5}$ cells $/ \mathrm{mL}$ and treated with different concentrations of the $50 \%$ ethanol-water crude extracts or melphalan for $24 \mathrm{~h}$. The cells were then washed and the supernatants were discarded. The NR was dissolved in $100 \mu \mathrm{L}$ of $0.33 \% \mathrm{HCl}$. The NR solution was added to each well, yielding a final concentration of $50 \mu \mathrm{g} / \mathrm{mL}$, and incubated at $37^{\circ} \mathrm{C}$ for $1 \mathrm{~h}$. The absorbance of the NR dye was detected using a dual-wavelength UV spectrometer (Anthos 2010; Biochrom, UK) at $520 \mathrm{~nm}$ with a reference wavelength of $650 \mathrm{~nm}$. The percent cytotoxicity compared with untreated cells was determined and calculated as the \%-cytotoxicity. A plot of \%-cytotoxicity $v s$. test compound concentration was used to calculate the $\mathrm{IC}_{50}$. The selectivity index (SI) was calculated from the $\mathrm{IC}_{50}$ of the $50 \%$ ethanol-water crude extracts in normal cells $v s$. cancer cells to indicate the cytotoxic selectivity (i.e., safety) of the $50 \%$ ethanol-water crude extracts against cancer cells $v s$. normal cells.

\section{Apoptosis induction assays DNA fragmentation detection assay}

DNA fragmentation was used as a proxy for apoptosis induction. After treatment of cancer cells with $500 \mu \mathrm{g} /$ $\mathrm{mL}$ of the $50 \%$ ethanol-water extracts and $80 \mu \mathrm{g} / \mathrm{mL}$ of melphalan for $24 \mathrm{~h}$, the cells were collected and washed with medium. The cell suspensions were transferred to microcentrifuge tubes $(1.5 \mathrm{~mL})$ and centrifuged at $500 \times g$ (PMI-Labortechnik GmbH, Germany) for $5 \mathrm{~min}$, followed by collection of the cell pellets. The DNA in the cell pellets was extracted using a FlexiGene DNA Kit according to the web-published FlexiGene ${ }^{\circledR}$ DNA Handbook. Aliquots $(2 \mu \mathrm{g})$ of the DNA were analyzed by electrophoresis in $1.8 \%$ agarose gels containing $0.1 \%$ ethidium bromide. After the electrophoresis, the DNA fragments were analyzed using a UV-illuminated camera (Syngene, UK).

\section{Annexin V-FITC staining for apoptosis detection by flow cytometry}

An Annexin V-FITC and propidium iodide (PI) double staining method was used according to Moosavi and Yazdanparast [9], with some modifications. The cells were seeded in a 24-well plate at a density of $5 \times 10^{5}$ cells $/ \mathrm{mL}$, supplemented with DMEM containing $10 \%$ FBS, and incubated in a $5 \% \mathrm{CO}_{2}$ incubator at $37^{\circ} \mathrm{C}$ for $24 \mathrm{~h}$. The test compounds were added to the wells to give final concentrations of $500 \mu \mathrm{g} / \mathrm{mL}$ for the respective $50 \%$ ethanol-water extracts and $80 \mu \mathrm{g} / \mathrm{mL}$ for melphalan. The exposure time between the cells and the test compounds was $24 \mathrm{~h}$. Subsequently, the cells were washed with $1 \times$ phosphate-buffered saline (PBS), trypsinized, and transferred to microcentrifuge tubes $(1.5 \mathrm{~mL})$. The cells were centrifuged at $500 \times g$, and the cell pellets were resuspended with $195 \mu \mathrm{L}$ of binding buffer $(10 \mathrm{mM}$ HEPES/NaOH pH 7.4, $140 \mathrm{mM} \mathrm{NaCl}, 2.5 \mathrm{mM} \mathrm{CaCl}_{2}$ ). The cells were then stained with $5 \mu \mathrm{L}$ of Annexin VFITC in the dark at room temperature for $5 \mathrm{~min}$ and centrifuged at $500 \times g$ to collect the cell pellets. Next, the cell pellets were resuspended in $190 \mu \mathrm{L}$ of binding buffer and stained with $10 \mu \mathrm{L}$ of PI for 10 min under the same conditions. Finally, the fluorescence intensity was determined using a flow cytometer (FACSCanto II; BD Biosciences, USA), and the percentages of cells in different populations were quantified using a quadrant marker.

\section{Statistical analysis}

The data were represented as means \pm standard deviation $(\mathrm{SD})(\mathrm{n}=3)$. The statistical significance of differences in 
multiple-group comparisons were evaluated by a oneway analysis of variance followed by Tukey's Honestly Significant Difference test using SPSS version 11.5 (SPSS Inc., USA). A two-tailed Student's $t$-test was also performed. Values of $P<0.05$ were considered statistically significant within a $95 \%$ confidence interval.

\section{Results and discussion}

The 50\% ethanol-water crude extracts of the six herbs showed moderate cytotoxicity toward HepG2 and Vero cells, except for the lack of activity of the $D$. winitii and B. ovata extracts toward Vero cells $\left(\mathrm{IC}_{50}>500 \mu \mathrm{g} /\right.$ $\mathrm{mL})$.

The $50 \%$ ethanol-water crude extracts of the six herbs exhibited different degrees of cytotoxicity toward HepG2 cells, with $\mathrm{IC}_{50}$ values ranging from 100 to $500 \mu \mathrm{g} / \mathrm{mL}$, and showed significant differences from untreated cells $(P=0.000)$. The $T$. triptera extract showed high cytotoxicity toward HepG2 cells $\left(\mathrm{IC}_{50}=148.7 \pm 12.3 \mu \mathrm{g} / \mathrm{mL}\right)$. A significant difference was found between the cytotoxicity of melphalan and the 50\% ethanol-water crude extracts $(P=0.000)$. All of the $50 \%$ ethanol-water crude extracts showed significantly lower cytotoxicity than melphalan $\left(\mathrm{IC}_{50}=37.7 \pm 9.8 \mu \mathrm{g} / \mathrm{mL}\right)(P=0.000)$.

T. triptera and T. mucronata, which are both in the genus Terminalia of the family Combretaceae, were the most cytotoxic herbs toward HepG2 cells. In HepG2 cells, no significant differences in cytotoxicity were observed between $T$. triptera and $T$. mucronata $(P=1.000), T$. triptera and $A$. harmandii $(P=0.862), D$. winitii and $B$. ovate $(P=1.000), D$. winitii and $A$. harmandii $(P=0.419), B$. ovata and $A$. harmandii $(P=0.385)$, and $T$. mucronata and $A$. harmandii $(P=0.862)$. For Vero cells, no significant differences in cytotoxicity were observed between $D$. winitii and $B$. ovata $(P=1.000)$ and $T$. triptera and $T$. mucronata $(P=0.999)$.

The cytotoxicity and SI values of the plant extracts for HepG2 cells $v s$. Vero cells are summarized in Table 2. The extracts showing significant differences in cytotoxicity (Student's $t$-test) toward HepG2 cells compared with normal Vero cells similar to that of melphalan $(P=0.000)$ were $C$. oblongifolius $(P=0.002), D$. winitii, $(P=0.000), B$. ovata $(P=0.000)$, and $A$. harmandii $(P=0.005)$. None of the extracts had an SI value of $>3$ for classification as highly selective.

The 50\% ethanol-water extracts had only moderate anticancer activity, as evaluated by apoptosis induction. The distinct DNA ladder in HepG2 cells showed the characteristics of late-stage apoptosis after treatment with melphalan for $24 \mathrm{~h}$ (Figure 1). The extracts of $D$. winitii and T. triptera showed subtle DNA ladders, while the other extracts did not induce the late-stage of apoptosis in HepG2 cells.
Table 2 Classification of the cytotoxicity and selectivity index (SI) of the $50 \%$ ethanol-water crude extracts in HepG2 cells vs. Vero cells

\begin{tabular}{lll}
\hline Cytotoxicity & SI Value & HepG2 vs. Vero \\
\hline Very strong cytotoxicity & $\mathrm{SI} \geq 3$ & - \\
\hline$\left(I C_{50}<10 \mu \mathrm{g} / \mathrm{mL}\right)$ & & \\
\hline Strong cytotoxicity & $\mathrm{SI} \geq 3$ & - \\
\hline$\left(I C_{50} 10-100 \mu \mathrm{g} / \mathrm{mL}\right)$ & $\mathrm{SI}<3$ & - \\
\hline Moderate cytotoxicity & $\mathrm{SI} \geq 3$ & - \\
\hline$\left(I C_{50} 100-500 \mu \mathrm{g} / \mathrm{mL}\right)$ & $\mathrm{SI}<3$ & $\frac{\text { B. ovata }(>2.72)}{\text { D. winitii }(>2.44)}$ \\
\hline & & $\frac{\text { A. harmandii }(1.89)}{\text { T. triptera }(0.92)}$ \\
\hline & & $\frac{\text { T. mucronata }(0.85)}{\text { C. oblongifolius }(0.63)}$ \\
\hline
\end{tabular}

However, the DNA ladder assay has lower sensitivity for apoptosis detection than flow cytometry [10], because DNA ladder formation can only be clearly observed when the extent of oligonucleosomal cleavage is remarkable. Moreover, necrotic cells can also generate DNA fragments [11]. Therefore, the apoptosis findings obtained by Annexin V/PI staining, as detected by flow cytometry, may provide more details.

Percent cell populations at different death modes detected by Annexin V-FITC staining and flow cytometry after HepG2 cells treated with melphalan and 50\% ethanol-water extracts for $24 \mathrm{~h}$ were shown in Figure 2.

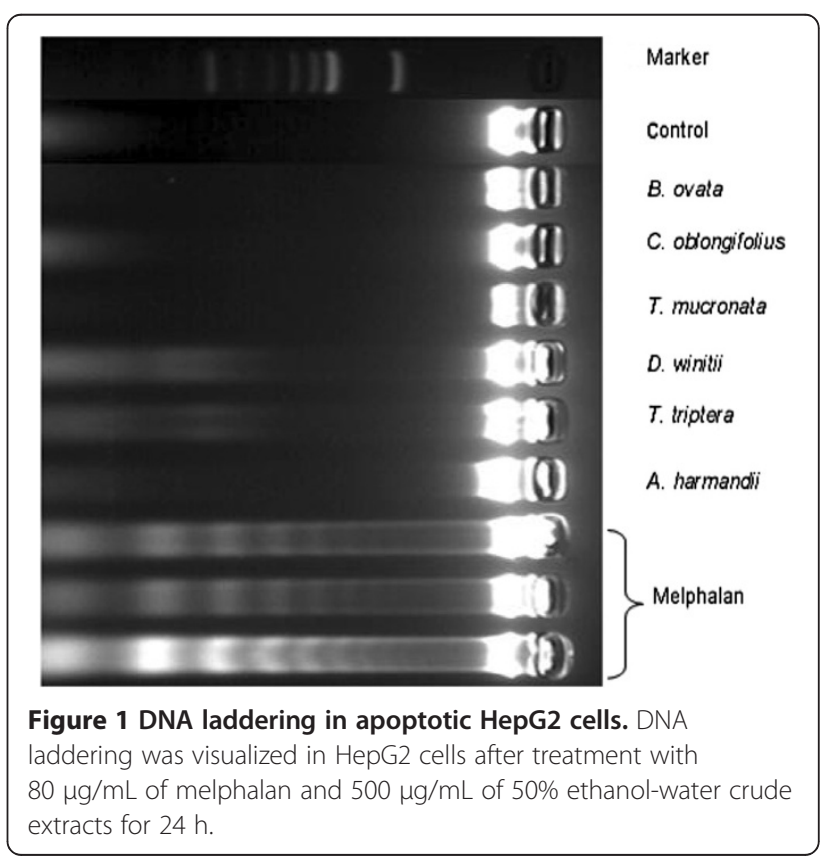




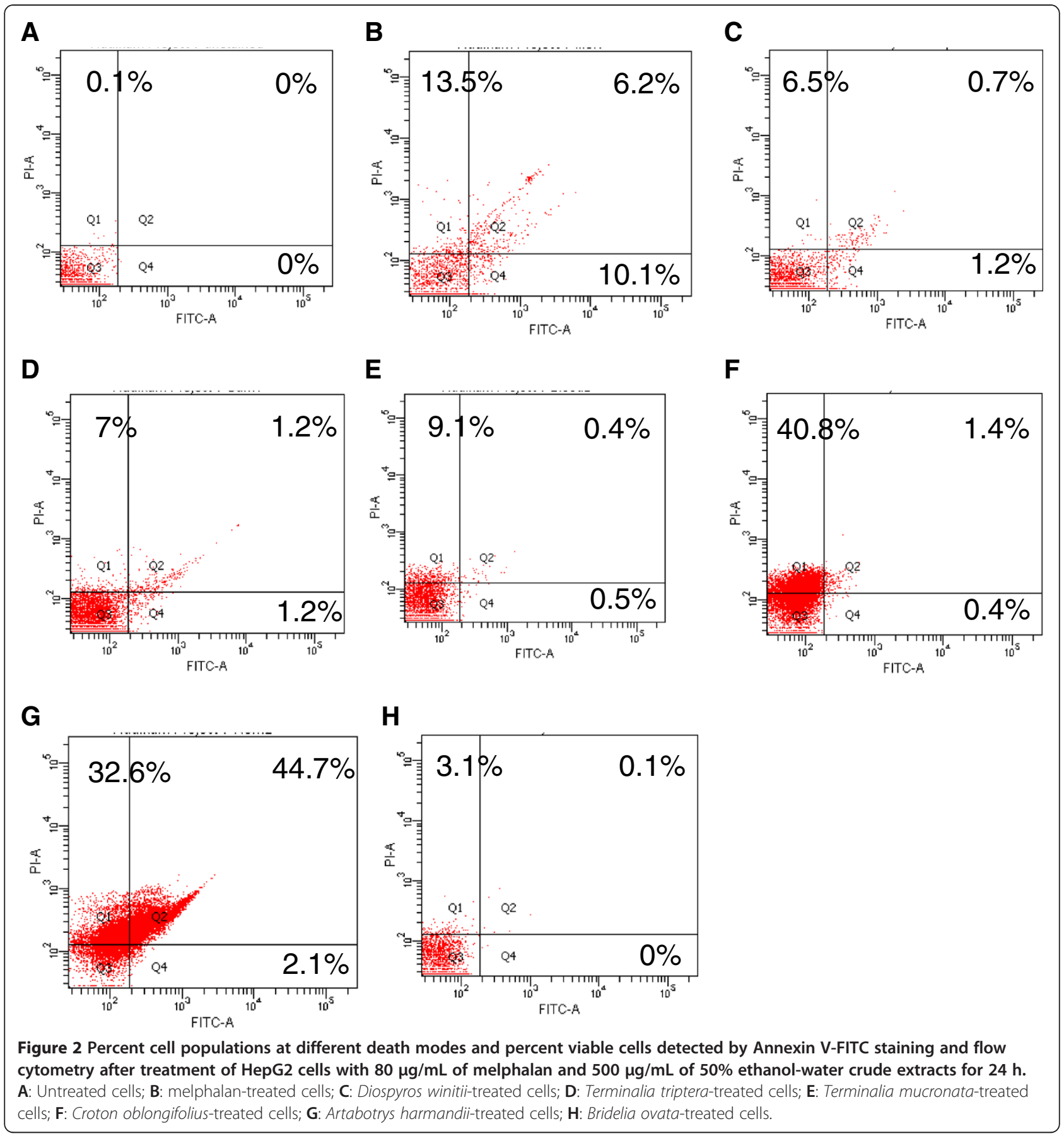

Results show that four extracts induced apoptosis vs. untreated HepG2 cells at the late stage, with the most effective being $A$. harmandii, $T$. triptera, $D$. winitii, and $C$. oblongifolius. Melphalan induced $10.1 \%$ early-stage apoptosis and $6.2 \%$ late-stage apoptosis, and also caused $13.5 \%$ necrosis. Melphalan induced a significantly different \%-apoptosis than the plant extracts $(P=0.000)$. Moreover, significant differences in the mean \%-apoptosis were observed between $D$. winitii and $A$. harmandii $(P=0.000)$, T triptera and $A$. harmandii $(P=0.000)$, T. mucronata and $A$. harmandii $(P=0.000), C$. oblongifolius and $A$. harmandii $(P=0.000)$, and $A$. harmandii and $B$. ovata $(P=0.000)$. Among the six herbs, the $A$. harmandii extract induced the highest degree of apoptosis by causing $2.1 \%$ early-stage apoptosis and $44.7 \%$ late-stage apoptosis with $32.6 \%$ high necrosis in HepG2 cells. 
B. ovata, $D$. winitii, and $A$. harmandii were potentially cytotoxic with relatively high selectivity for HepG2 cells. Only A. harmandii showed high apoptosis in HepG2 cells (especially late-stage apoptosis) and a relatively high necrosis effect. $B$. ovata and $D$. winitii induced relatively higher necrosis in HepG2 cells than apoptosis, based on Annexin V/PI staining. These data suggested that the cell death among HepG2 cells induced by these two herbs was mostly necrosis. Since necrosis is an irreversible inflammatory form of cell death, it has some implications for cancer therapy [12]. Thus, B. ovata and D. winitii may be of interest for further investigations into their anticancer activity via necrosis as the mode of death.

Since 50\% ethanol-water crude extracts were used in the present study, standardization of the three potential crude extracts for future quality control experiments was necessary. We then determined whether the phytochemicals in the crude extracts were associated with the apoptosis effects. GC-MS analyses of the D. winitii, T. triptera, and $A$. harmandii extracts were conducted. The GC peaks obtained were used for further chemical constituent identification using the MS database. The GCMS analyses of the three crude extracts are shown in Additional files 1, 2, and 3 and the main chemical constituents are presented in Table 3.
The GC chromatograms of the T. triptera, D. winitii, and $A$. harmandii extracts differed significantly. A GC peak of the retention time ranging from 23 to $24 \mathrm{~min}$ was found in the GC chromatograms of the three crude extracts, indicating that they may contain similar constituents. This peak region could not be identified by MS because the peaks were merged. The MS profiles of all of the crude extracts revealed that the crude extracts of the three plants had two identical compounds, namely vinylphenol and hexadecanoic acid, which are the most common phenolic and fatty acids in plants. Based on the identification of the extant phytochemicals in the $50 \%$ ethanol-water crude extracts using the MS database, the $50 \%$ ethanol-water crude extracts possessed the same GC retention time. However, the whole MS spectra of the individual $50 \%$ ethanol-water crude extracts appeared different, indicating the presence of different compounds.

This study is the first report of cell-based assays for the anticancer effects of selected plants. A. harmandii was considered to have the most potential for further study regarding its apoptosis-inducing mechanism, based on the findings of the flow cytometry analyses. Its bioactive constituents and anticancer activity toward other cancer cell types should be determined.

Table 3 GC-MS profiles of the three potential plant $50 \%$ ethanol-water crude extracts

\begin{tabular}{|c|c|c|c|c|}
\hline Plants & Retention time (min) & $\%$ of total area & Mass spectra & Assigned compounds \\
\hline \multirow[t]{4}{*}{ T triptera } & 11.94 & 7.126 & $51,65,91,119,120$ & 4-Vinylphenol \\
\hline & 12.29 & 6.335 & $53,63,69,81,97,109,126$ & 5-Hydroxymethyl-2-furancarboxaldehyde \\
\hline & 29.52 & 3.220 & $\begin{array}{l}60,73,83,97,115,129,143 \\
157,171,185,199,213,227,256\end{array}$ & n-Hexadecanoic acid \\
\hline & 36.34 & 5.579 & $57,71,107,135,320$ & $\begin{array}{l}\text { 3-Bis(methylthio)methylene-2-methyl-4- } \\
\text { (methoxyphenyl) }\end{array}$ \\
\hline \multirow[t]{6}{*}{ D. winitii } & 14.45 & 1.784 & $51,77,107,135,150$ & 2-Methoxy-4-vinylphenol \\
\hline & 15.44 & 2.605 & $65,96,111,139,154$ & Phenol,2,6-dimethoxy- \\
\hline & 21.92 & 2.464 & $111,126,141,169,184$ & $\begin{array}{l}\text { Acetaldehyde,(3-chloro-5,5-dimethyl-2- } \\
\text { cyclohexane-1-ylidene) }\end{array}$ \\
\hline & 24.85 & 8.367 & $77,91,124,137,180$ & $\begin{array}{l}\text { 1,7-Dimethyl-4,4a,5,6-tetrahydropyrido- } \\
1 \mathrm{H}[1,2 \text {-b]pyridazin-2)3H)one }\end{array}$ \\
\hline & 29.53 & 8.318 & $\begin{array}{l}60,73,83,97,115,129,143,157 \\
171,185,199,213,227,256\end{array}$ & n-Hexadecanoic acid \\
\hline & 36.35 & 5.656 & $57,107,135,152,320$ & $\begin{array}{l}\text { 4-Trimethylsilyl-3-(1-phenylthiobutyl)pent- } \\
\text { 3-en-2-one }\end{array}$ \\
\hline \multirow[t]{5}{*}{ A. harmandii } & 14.43 & 2.260 & $51,77,107,135,150$ & 2-Methoxy-4-vinylphenol \\
\hline & 24.88 & 10.966 & $77,91,124,137,180$ & 2-(2-Oxoethyl)-cis-bicyclo[3.3.0]octane-3,7dione \\
\hline & 29.64 & 8.398 & $\begin{array}{l}60,73,83,97,115,129,143,157 \\
171,185,199,213,227,256\end{array}$ & Hexadecanoic acid \\
\hline & 39.10 & 27.801 & $57,74,98,112,134,239,257,299$ & $\begin{array}{l}\text { Hexadecanoic acid, 2-hydroxy-1- } \\
\text { (hydroxymethyl)ethyl ester) }\end{array}$ \\
\hline & 42.17 & 18.451 & $\begin{array}{l}43,57,74,98,112,134,154,267 \\
284,298,327,341,358\end{array}$ & Glyceryl monosterate \\
\hline
\end{tabular}




\section{Conclusions}

The $50 \%$ ethanol-water crude extracts of $D$. winitii, $T$. triptera, and $A$. harmandii showed anticancer activity in vitro.

\section{Additional files}

Additional file 1: (A) GC-MS chromatogram $10 \mathrm{mg} / \mathrm{mL} T$. triptera crude extract in DMSO. (B-E) Mass spectra of the crude extract with a respective retention time of $11.94,12.29,29.52$, and $36.34 \mathrm{~min}$

Additional file 2: (A) GC-MS chromatogram of $10 \mathrm{mg} / \mathrm{mL} D$. winitii crude extract in DMSO. (B-G) Mass spectra of the crude extract with a respective retention time of 14.45, 15.44, 21.92, 24.85, 29.53 and 36.35 $\min$

Additional file 3: (A) GC-MS chromatogram of $10 \mathrm{mg} / \mathrm{mL} A$. harmandii crude extract in DMSO. (B-F) Mass spectra of the crude extract with a respective retention time of $14.43,24.88,29.6,39.10$ and $42.17 \mathrm{~min}$

\section{Abbreviations}

DMEM: Dulbecco's modified Eagle's medium; DMSO: dimethylsulfoxide; FBS: fetal bovine serum; GC-MS: gas chromatography/mass spectrometry; NR: neutral red; PBS: phosphate-buffered saline; Pl: propidium iodide; SI: selectivity index; UV: ultraviolet.

\section{Competing interests}

The authors declare that they have no competing interests.

\section{Authors' contributions}

NW designed the study, supervised the experiments, and wrote and revised the manuscript. AN performed the experiments. TT performed the plant authentication. BS provided the plant extracts. All the authors read and approved the final version of the manuscript.

\section{Acknowledgments}

This work was supported by Khon Kaen University through the Plant Genetics Conservation Project under the patronage of Her Royal Highness Princess Maha Chakri Sirindhorn (fiscal year 2011) (54122). AN was supported by a scholarship from the Graduate School, Khon Kaen University. The authors would like to thank the Bureau of The Royal Household for permission to conduct the research, Ms. Chantima Saoha and Ms. Cholpajsorn Junhom for technical assistance, and Mr. Bryan Roderick Hamman and Mrs. Janice Loewen-Hamman for assistance with the Englishlanguage presentation of the manuscript.

\section{Author details}

${ }^{1}$ Faculty of Pharmaceutical Sciences, Khon Kaen University, Khon Kaen, 40002 Thailand. ${ }^{2}$ Center for Research and Development of Herbal Health Products (CRD-HHP), Faculty of Pharmaceutical Sciences, Khon Kaen University, 123 Mittrapap Road, Muang District, Khon Kaen, 40002, Thailand. ${ }^{3}$ Graduate School, Faculty of Pharmaceutical Sciences, Khon Kaen University, Khon Kaen, 40002, Thailand. ${ }^{4}$ Center for Research and Development of Medical Diagnostic Laboratories (CMDL), Khon Kaen University, Khon Kaen, 40002 , Thailand. ${ }^{5}$ Faculty of Associated Medical Sciences, Khon Kaen University, Khon Kaen, 40002, Thailand.

Received: 5 January 2012 Accepted: 1 June 2012

Published: 10 June 2012

\section{References}

1. Machana S, Weerapreeyakul N, Barusrux S, Nonpunya A, Sripanidkulchai B, Thitimetharoch T: Cytotoxic and apoptotic effects of six herbal plants against the human hepatocarcinoma (HepG2) cell line. Chin Med 2011, 6:39.

2. Salatino A, Salatino MLF, Negri G: Traditional uses, chemistry and pharmacology of Croton species (Euphorbiaceae). J Braz Chem Soc 2007, 18:11-33.
3. Shugang L, Gilbert Michael G, Frank White: Flora of China. Vol. 15th edition. Beijing: Science Press and Missouri: Botanical Garden Press; 2007.

4. Jemal A, Bray F, Center MM, Ferlay J, Ward E, Forman D: Global Cancer Statistics. CA Cancer J Clin 2011, 61:69-90.

5. Roengsumran S, Petsom A, Kuptiyanuwat N, Vilaivan T, Ngamrojnavanich N, Chaichantipyuth C, Phuthong S: Cytotoxic labdane diterpenoids from Croton oblongifolius. Phytochemistry 2001, 56:103-107.

6. Au JLS, Panchal N, Li D, Gan Y: Apoptosis: A new pharmacodynamic endpoint. Pharm Res 1997, 14:1659-1671.

7. Martinez MM, Reif RD, Pappas D: Detection of apoptosis: A review of conventional and novel techniques. Anal Methods 2010, 2:996-1004

8. Fotakis G, Timbrell JA: In vitro cytotoxicity assays: Comparison of LDH, neutral red, MTT and protein assay in hepatoma cell lines following exposure to cadmium chloride. Toxicol Lett 2006, 160:171-177.

9. Moosavi MA, Yazdanparast R: Distinct MAPK signaling pathways, p21 upregulation and caspase-mediated p21 cleavage establishes the fate of U937 cells exposed to 3-hydrogenkwadaphnin: differentiation versus apoptosis. Toxicol Appl Pharmacol 2008, 230:86-96.

10. Yasuhara S, Zhu Y, Matsui T, Tipirneni N, Yasuhara Y, Kaneki M, Rosenzweig A, Martyn JAJ: Comparison of comet assay, electron microscopy, and flow cytometry for detection of apoptosis. J Histochem Cytochem 2003, 51:873-885.

11. Elmore S: Apoptosis: A review of programmed cell death. Toxicol Pathol 2007, 35(4):495-516.

12. Amaravadi RK, Thompson CB: The roles of therapy-induced autophagy and necrosis in cancer treatment. Clin Cancer Res 2007, 13:7271-7279.

doi:10.1186/1749-8546-7-15

Cite this article as: Weerapreeyakul et al:: Evaluation of the anticancer potential of six herbs against a hepatoma cell line. Chinese Medicine 2012 7:15.

\section{Submit your next manuscript to BioMed Central and take full advantage of:}

- Convenient online submission

- Thorough peer review

- No space constraints or color figure charges

- Immediate publication on acceptance

- Inclusion in PubMed, CAS, Scopus and Google Scholar

- Research which is freely available for redistribution 